\title{
Energy Status, Energy Mix and Renewable Energy Potentials of Nigeria
}

\author{
F. B. Elehinafe ${ }^{1}$, O. B. Okedere ${ }^{2}$, A. O. Mamudu ${ }^{1} \&$ M. E. Emetere ${ }^{1}$ \\ ${ }^{1}$ Department of Chemical Engineering, College of Engineering, Covenant University, Ota, Ogun State, Nigeria \\ ${ }^{2}$ Department of Chemical Engineering, Faculty of Engineering, Osun State University, Osogbo, Nigeria \\ Correspondence: F. B. Elehinafe, Department of Chemical Engineering, College of Engineering, Covenant \\ University, Ota, Ogun State, Nigeria.
}

Received: January 19, 2021

Accepted: May 18, 2021

Online Published: May 20, 2021

doi:10.5539/eer.v11n1p50

URL: https://doi.org/10.5539/eer.v11n1p50

\begin{abstract}
The review looked at Nigeria's energy status, energy mix, and renewable energy potentials in order to provide information on the opportunities in the country's energy sector that could be taken advantage of, by people, researchers, investors, businesses, and governments. This is critical in light of the existing energy supply gaps hence the need for sustainable energy production.
\end{abstract}

Keywords: energy status, energy mix, renewable energy, potentials, Nigeria

\section{Introduction}

The importance of long-term energy production in Nigeria cannot be overlooked. This is not due to the country's increased population and industrial growth. According to the most recent population census, Nigeria had a population of about 140 million people (NPC, 2006). Based on a $2.5 \%$ annual population growth rate, this is currently projected to be between 180 and 200 million people. According to emerging trends, Nigeria's energy demand has already surpassed its supply, and the situation is even worse in the southwestern region of the country, which houses the majority of the country's manufacturing industries, where most residential and industrial users have less than four hours of electricity per day (Nwachukwu, et al., 2014). The energy consumption estimate in Figure 1 depicts Nigeria's geometric energy demands, with population and industrial development as the driving forces.

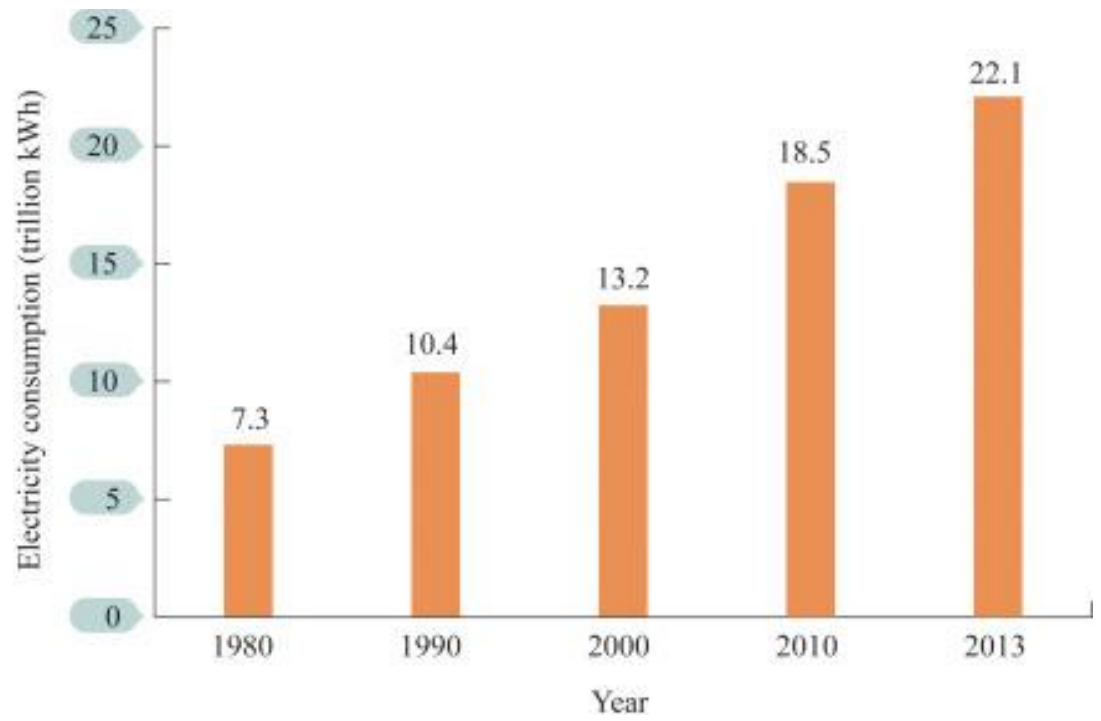

Figure 1. Energy consumption in Nigeria (Liu, 2015) 
According to Ekundayo et al., (2018), population growth is widely used to estimate a place's energy needs, and a higher standard of living is inferred based on per capita energy consumption of $3 \mathrm{~kW}$, which is actually a quarter of what it is in the United States of America. This may seem to be a tough fit, some countries around the world have made huge strides and are now running at conservative figures around $1 \mathrm{~kW}$ per capita consumption (Nwachukwu et al., 2014). Nigeria, with a population of approximately 140 million people in 2006 (NPC, 2006), relies heavily on electrical energy from the national grid, with $0.03 \mathrm{~kW}$ per capita energy consumption dependent on generation capacity.

Using the experience of other countries, Nigeria's energy needs (180 to 200 million people) are expected to be 32 000 to 40000 megawatts (MW) to ensure better living conditions. While this will result in a conservative figure of $1 \mathrm{~kW}$ per capita energy consumption in South Africa, it will provide a good platform for the country's economic revitalization while progressive and concerted attempts to broaden the energy base to meet potential energy requirements continue. This paper analyzes Nigeria's energy status, energy mix, and renewable energy potentials in order to identify research, investment, and exploitation gaps in the country's energy sector.

\section{Energy Status of Nigeria}

Despite Nigeria's abundance of conventional energy resources (oil, natural gas, lignite, and coal) as well as renewable energy sources (wood, solar, hydropower, and wind), the energy supply-demand gap remains enormous. The most widely used energy resource in the world, electricity, has been volatile (Okafor and Joe-Uzuegbu, 2010). Nigeria's energy crisis is largely due to population growth, insufficient production, and weak energy sector management. The current available 4602.4 MW cannot accommodate a population of over 200 million people with an annual population growth rate of 2.5\% (Ekundayo et al., (2018); Okafor, 2017; Sambo, 2018). Established power plants, as shown in Table 1, are currently operating at far below their installed capacities, and many of them have components that require renovation, retrofitting, or upgrading. Furthermore, approximately $52 \%$ of the population lives in rural areas and does not raise enough money to pay for fuel or electricity (World Bank, 2006).

Table 1. Power Generation in Nigeria

\begin{tabular}{cccc}
\hline Site & Type & $\begin{array}{c}\text { Installed Capacity } \\
(\mathrm{MW})\end{array}$ & $\begin{array}{c}\text { Available Capacity } \\
(\mathrm{MW})\end{array}$ \\
\hline Kainji & Hydro & 760 & 438.86 \\
Jebba & Hydro & 578.4 & 529.4 \\
Shiroro & Hydro & 600 & 488.82 \\
Egbin & Thermal & 1320 & 694.97 \\
AES & Thermal & 315 & 233.91 \\
Sapele & Thermal & 1020 & 156.60 \\
Afam & Thermal & 709.6 & 82.12 \\
Geregu & Thermal & 414 & 305.14 \\
Omotos & Thermal & 335 & 256.58 \\
Olorunsogo & Thermal & 335 & 271.46 \\
Okpai & Thermal & 480 & 394.56 \\
Omoku & Thermal & 150 & 87.27 \\
Delta & Thermal & 912 & 211.67 \\
Total & & 8039 & 4176.24 \\
\hline
\end{tabular}

Source: PHCN (2009)

Several types of energy resources are abundant in Nigeria. The country has the world's sixth largest crude oil reserve. Nigeria is thought to have a crude oil reserve of 36.2 billion barrels. With confirmed reserves of approximately 185 trillion cubic feet, it is rapidly becoming a significant gas field (TCF) (Ahmed et al., 2012). Oil and gas reserves are mainly found in the Niger Delta, Benin Bight, and Gulf of Guinea. The majority of oil exploration activities take place in deep and ultra-deep offshore areas. Oil exploration and prospecting are also underway in the country's northeastern region, around the Chad basin. The reserves of lignite and coal were expected to be 2.7 billion tons, while the reserves of tar sand were estimated to be 31 billion barrels of oil equivalent. The hydroelectricity spots discovered in Nigeria have a total capacity of nearly 14,250 MW. In addition 
to the above, it was mentioned that Nigeria has significant biomass resources for both local and modern energy needs, as well as electricity generation. (Elehinafe et al., 2017; Ighodaro, 2010). Nigeria's energy reserves capacity and capacities are shown in Table 2.

Efforts are currently ongoing in Nigeria to establish policies that will ensure that the country has enough electricity. According to studies, all aspects of power supply (generation, transmission, and distribution) need to be overhauled in order to increase energy availability. Nigeria's installed electricity capacity from various power generating units was about 6,159 MW, with just around half of that available for use (Sonibare, 2010). Between 1966 and 1990, these stations were constructed. The Federal Government's National Integrated Power Projects (NIPPs), upstream petroleum operators' incentives to construct and operate electricity generation plants under the joint venture scheme, and the Nigerian electricity regulation commission's licensing of independent power producers (IPP) are currently being implemented to boost the energy situation (Sambo, 2018). This is still primarily accomplished by a combination of hydro and thermal systems. A transmission network, often referred to as the national grid, connects power generation, distribution, and substations all together.

Table 2. Nigeria's Energy Reserve/Capacity

\begin{tabular}{llc}
\hline Resource type & Reserves & Reserve (BTOE) \\
\hline Crude oil & 36.2 billion barrels & 4,896 \\
Natural gas & 166 trillion SCF & 4,465 \\
Coal and lignite & 2.7 billion tonnes & 1,882 \\
Tar sands & 31 billion barrels of oil equivalent & 4,216 \\
Subtotal fossil & 15,459 & \\
Hydro power large Scale & $11,000 \mathrm{MW}$ \\
Hydro power Small Scale & $3,250 \mathrm{MW}$ \\
Fuel wood & $13,071,464$ ha \\
Animal waste & 61 million tonnes/year \\
Crop residue & 83 million tones/year & \\
Solar radiation & $3.5-7.0 \mathrm{~kW}$ h/m $2 /$ day & \\
Wind & $2-4 \mathrm{~m} / \mathrm{s}$ annual average at height $10 \mathrm{~m}$ \\
\hline
\end{tabular}

Source: Oyedepo et al. (2018)

The National Control Centre in Osogbo is in charge of monitoring and distributing the electricity produced throughout the country. As shown in Table 2, the country's electricity grid currently consists of 14 generating stations (11 thermal and 3 hydro) with a total installed capacity of 8,309 MW. Current electricity demand realities indicate that, despite ongoing efforts, installed generation capacity will not be sufficient to achieve the country's expected growth rate for achieving the Millennium Development Goals (MDGs) and Vision 20:20:20. (Sambo, 2018).

\section{Nigeria's Energy Mix}

Nigeria has an abundance of energy-generating potential. Natural gas, petroleum, tar sands, biomass, bio-mass, and other renewable energy sources such as massive hydroelectric, solar, wind, and tidal sources are among the available primary energy sources. Crude oil reserves are estimated to be about 40 billion barrels (Akorede et al., 2017), with an increase to about 55 million barrels expected in the not-too-distant future. There is also a large natural gas reserve, which is currently estimated to be about 2.7 billion cubic meters. The estimated size of tar sand deposits is still about 31 billion tons, while coal deposits are estimated to be between 2 and 10 billion tons (IEA, 2012).

Nigeria's combined high, small, mini, and micro hydroelectricity capacity is estimated to be 10,000 MW, with 1,938.4 MW installed and 1,457.08 MW available (Oyedepo et al., 2018). The annual yield of Nigeria's wood resource is estimated to be around 22 million cubic meters on a sustainable basis, while the combined biomass capacity, which includes agricultural and animal wastes as well as wood residues, was estimated to be around 1931 million tons in 1990. (Akorede et al., 2017). These biomass resources have the potential to generate up to 1.2 PJ of energy (IEA, 2012). Similarly, the sun will provide about 1,500 PJ (roughly 258x106 bbl. of oil equivalent) for Nigeria on a yearly basis if solar collectors with a $5 \%$ efficiency are used over only $1 \%$ of the country's total land 
area for six months. In a similar vein, there are indications that the country's annual wind energy capacity ranges from 1,000 to 97,000 $\mathrm{kWh}$, and that geothermal energy harvesting feasibility is also high (Akorede et al., 2017).

Nigerians still rely on fewer clean energy sources such as firewood, crop residue, and bagasse for their household energy needs, despite the country's vast oil and gas reserves and high renewable energy potential. As of 2012, Nigeria's firewood consumption was estimated to be about 80 million cubic meters (roughly 25 million tons) (IEA, 2012). Fuelwood is commonly used for cooking and heating, as well as industrial applications at the cottage level and food processing. Despite the fact that conventional energy sources are typically excluded from commercial energy consumption estimates, they currently account for about $55 \%$ of Nigeria's primary energy needs (IEA, 2012). This is based on the fact that their importance deteriorates as the economy of the country evolves. Nigeria's energy sources are oil and gas, coal, and electricity on an industrial scale and in the formal sector.

On a daily basis, approximately 2.4 million barrels of oil are extracted, while approximately 4 billion scf of natural gas are produced. Natural gas output is projected to increase to 6 billion (scf/d) in the coming years, with gas sales expected to increase from 200 million scf/day to 3.5 billion scf/day over the same time span. Natural gas is used in Nigeria in a variety of ways. On a daily basis, about $45 \%$ of this gas is flared. Nigerian Liquefied Natural Gas Company (NLNG) exports the remainder, while Nigerian Gas Company (NGC) sells it domestically as fuel to thermal power plants and factories (Akinyemi et al., 2019). The use of LPG in households has been increasing in recent years.

Nigeria currently has four refineries located in the country, with a total installed capacity of 445,000 barrels of crude oil per day. These refineries produce petrol (PMS), diesel (AGO), kerosene, LPG, asphalt, and other products. From the early 1990s to the present, these refineries' installed capacity has been significantly reduced due to aging and deteriorated infrastructure, oil pipeline vandalism, and refinery theft, among other factors (CIA, 2012). For example, the NNPC supplied 79 million barrels of crude oil to refineries for various petroleum products in 2002, out of a total capacity of 160 million barrels at full capacity. In 2002, 3.9 billion litres of PMS were produced, out of a total annual demand of 10.95 billion litres at a rate of 30 million litres per day (CIA, 2012). As a result, Nigeria has a 7 billion liter deficit that must be made up by imports. Nigeria has relied on imported refined petroleum products to supplement domestic needs since the mid-1990s. Regardless, fluctuating global petroleum product rates, as well as the weakening of the Naira's value, have made it difficult to sell at politically correct prices $(\mathrm{PCP})$ at the pump - points of sale.

Liquefied Petroleum Gas (LPG) burns cleaner than PMS, but its output is still reliant on Nigerian refineries. As a result, issues affecting refineries have an effect on LPG demand. The four refineries have a combined annual LPG capacity of 0.488 million tonnes. Nonetheless, in 2012, the refineries collectively produced $40 \%$ less than in 2011, resulting in a supply of just 199,359 tonnes of LPG (National Bureau of Statistics, 2019). In the previous decade, this was the trend. Since 1980, Nigerians have been increasing their use of LPG. This can be attributed to the convenience and demand that LPG has over other energy sources among privileged urban dwellers. In 1981, the amount of LPG produced was approximately 48,000 tonnes, which was equal to the amount of LPG consumed. With the government's deliberate campaign to make gas use common, consumption increased to 156,000 tonnes in 1990 from 91,000 tonnes in 1987. LPG consumption was estimated to be about 175,000 tonnes in 1991, 199,359 tonnes in 2012, and 157.29 million tonnes in August of this year (National Bureau of Statistics, 2019). Domestic LPG demand in Nigeria is hampered by a variety of problems, ranging from inadequate logistics to transport products stocked at off-shore natural gas plant depots to deplorable refinery conditions.

Imports account for more than $80 \%$ of total public consumption. Nigeria's per capita intake, estimated at 1.66 kilograms per person in 2012, is still poor when compared to that of some African countries, let alone developed Western countries. According to a recent World Bank study, the target for the revitalization of Nigeria's homegrown LPG market is to achieve a consumption of $3.7 \mathrm{~kg} / \mathrm{annum} /$ person. This would bring about a yearly consumption of around 462,500 tonnes. Government, in light of the World Bank report on the need to redirect some products meant for exports for internal utilization, as of late endorsed around 350,000 tons of Butane annually from the facility of Exxon/Mobil to local market. According to Ugwu (2012), Nigeria's coal reserves are estimated to be around 271.08 million tons. Table 2 depicts Nigeria's future energy reserves.

\section{Renewable Energy Potential of Nigeria}

Renewable energy comes from resources that can be replenished or substituted. Renewable energy sources are described as those that can be replaced on a human time scale and have no or minimal negative environmental consequences. Solar, biomass, water, geothermal, and wind are the traditional sources of renewable energy classification (Akinyemi et al., 2019). The Energy Commission of Nigerian (ECN) evaluated the country's renewable energy sources in 2005. It addressed Nigeria's capacity to get her electricity grid operated entirely by 
renewable energy sources as soon as possible. According to Akinyemi et al., (2019) only $10 \%$ of rural families and $30 \%$ of the country's total population are currently connected to the grid. According to ECN (2005), Nigeria has one of the lowest power supply per capita rates on the planet, with 15,000 MW required compared to 6,050 MW available, resulting in intermittent power and a correspondingly high dependence on petroleum fuels in businesses and residential communities.

Table 3 illustrates how renewable energy resources contribute to Nigeria's targeted electricity production. Large and small hydropower, solar, and wind energy are the key renewable energy options in the reference growth scenario. By 2010, the aforementioned renewable energy resources were expected to account for roughly $13 \%$ of total energy resources. By 2030, shrill contribution is expected to rise to $36 \%$ of total energy output (Akinyemi et al., 2019).

Table 3. Target for Renewable Energy Contribution to Electricity Generation in Nigeria

\begin{tabular}{lccc}
\hline Resource & $2010(\mathrm{MW})$ & $2015(\mathrm{MW})$ & $2030(\mathrm{MW})$ \\
\hline Large hydro & 1,930 & 5,930 & 48,000 \\
Small hydro & 100 & 734 & 19,000 \\
Solar PV & 5 & 120 & 500 \\
Solar Thermal & 0 & 1 & 5 \\
Biomass & 0 & 100 & 800 \\
Wind & 1 & 20 & 40 \\
Total RE & 2,036 & 6,905 & 68,345 \\
Total Energy & 16,000 & 30,000 & 192,000 \\
Resources & 0 & 0 & 0 \\
Percentage of RE $(\%)$ & 13 & 23 & 36 \\
\hline
\end{tabular}

Source: Akinyemi et al., 2019

\subsection{Biomass Energy Potential in Nigeria}

Forage plants, crops, trees, shrubs, animal wastes, forestry wastes, and wastes produced by agricultural, industrial, and municipal enterprises make up Nigeria's biomass assets. They also include biomass from marine areas (Uzoma et al., 2011). Crops from the nation's agrarian areas, such as maize, sugarcane, barley, and sorghum, are the most promising feedstocks for the production of biofuels, as shown in Figure 2. Plant and crop biomass can be used to manufacture biofuels for small-scale industrial projects. Through anaerobic bacteria fermentation, the biomasses can also be used to manufacture inexpensive biogases. According to Uzoma (2011), biogases generated from agrarian residues, industrial wastes, and civil society wastes do not compete for water supplies, property, and crop plant manures, as bioethanol and biodiesel do, and thus reduce the threats posed by these wastes. Water hyacinth and water lettuce, animal dungs, industrial processing wastes, urban biomass refuse, agrarian residues, and biowastes from sewage are all viable feedstocks in Nigeria for profitably feasible biogas production (Simonyan and Fasina, 2013). 


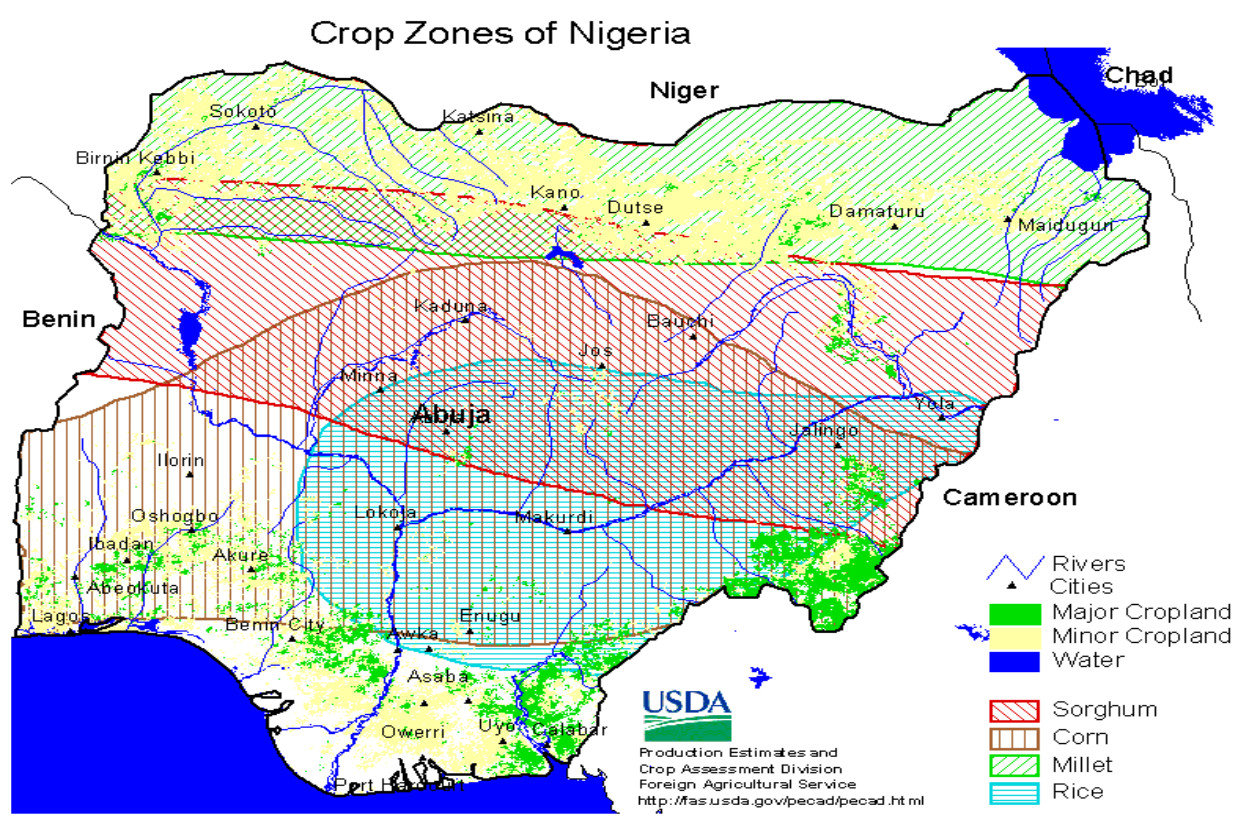

Figure 2. Crop zones of Nigeria (EIA, 2013)

Researchers estimate that Nigeria produces about $227,500,000 \mathrm{~kg}$ of animal waste every day. Nigeria could potentially deliver around 6.8 million $\mathrm{m}^{3}$ of biogas on a consistent basis, given that $1 \mathrm{~kg}$ of animal waste can generate up to $0.03 \mathrm{~m}^{3}$ of biogas. Despite the fact that biogas innovation is not common in Nigeria, various scientific researchers have been working on the technologies, developments, and policy aspects of commercial biogas development in the country. Researchers have done some research on reactor designs that could lead to an improvement in anaerobic digesters (Simonyan and Fasina, 2013). Other important bio resources associated with the timber industry include wood waste and sawdust. Biomass burners are currently available for cooking with sawdust and wood shavings. In both rural and urban areas, the use of biomass as a source of energy is currently limited to heat applications as a fuel for agricultural produce drying and food cooking.

Expanding the contribution of biomass-based energy sources to the global energy supply necessitates a dependable, cost-effective, and long-term production chain, as well as transportation and conversion technologies for biomass feedstocks (Sumit et al., 2014). Similarly, the technologies that allow biomass to be converted into value-added energy carriers must be affordable, reliable, safe, environmentally friendly, and adaptable. Biomass gasification has a lot of potential and could be a crucial enabling technology for the advancement of unified and adaptable bio-energy techniques (Audu and Aluyor, 2012). Electricity, hydrogen, and Fisher-Tropsch can all be produced or co-produced with it. There is no doubt that Nigeria has fair potential for biomass production. Biomasses have remained the primary source of energy for home cooking, industrial and domestic heating, and drying in Nigeria (Sumit et al., 2014). Biomasses can be used to produce renewable power and materials with ample funding and scientific analysis. Consider that electricity production accounts for $10 \%$ of arable land $(3,020,000 \mathrm{ha})$. With a yield of 10 tons of biomass per hectare, a total of 30,200,000 tons of biomass will be generated. According to research, a woody biomass's average High Heating Value (HHV) is $19.73+0.98 \mathrm{MJ} / \mathrm{kg}$, with a possible loss of $1.4 \mathrm{MJ} / \mathrm{kg}$ due to latent heat of vaporization of inherent moisture material (Audu and Aluyor, 2012).

Despite the fact that growing food crops is a key component of Nigeria's agrarian policy, the importance of power generation cannot be overstated. Biomass farming has the potential to have a major positive impact on Nigeria's economy. Crops that can be raised for energy generation have the greatest potential for bio-energy feedstocks in the country, whether as whole biomass, bio-waste, or bio-residues (ECN, 2005). In any case, having easy access to arable land is a prerequisite for determining ability. Artificial or natural manures, as well as other inputs, have a significant impact on the continuous development of energy crops, but ligno-cellulosic crops have lower requirements (Sumit et al., 2014). Biomasses are a hot potential source for converting plant materials into usable energy or fuel for internal combustion engines. Land use and bioenergy generation administration are critical in determining the absolute energy and environmental life cycle sustainability of bio-based renewable fuels (Sambo, 2018). 


\subsection{Hydropower Potential in Nigeria}

It is because of the difference in heights between its storage level and the receiving water into which it is emitted, hydropower is derived from the potential energy derivable from water (Figure 3). A turbine converts energy into electric current at a high rate of efficiency, which produces power. As Sambo (2018) observed, hydropower can be huge or small depending on the amount of water released and the quality of the dropping, i.e. pressure head. Around two-thirds of Nigeria's arable land is in the River Niger's watershed, which drains into the Atlantic Ocean in the Niger Delta Region, with major tributaries such as the River Benue in the northeast, the River Kaduna in the north central portion, the River Sokoto in the northwest, and the River Anambra in the southeast. The Niger River is Africa's third longest river and the fifth largest in terms of water discharge (ECN, 2005; Ismaila, 2017).

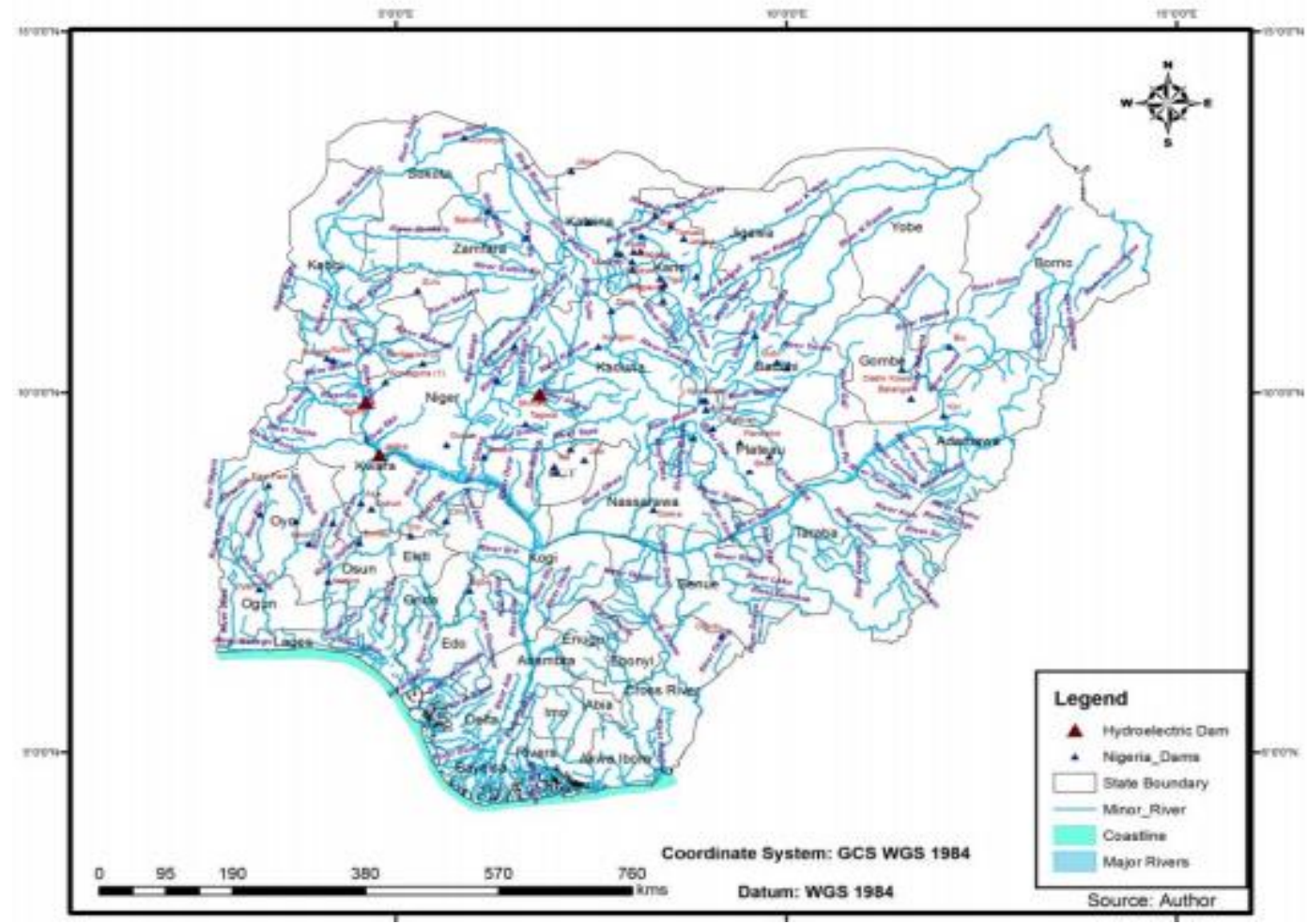

Figure 3. Hydropower zones of Nigeria (Olaide et al., 2017)

A few rivers in the basin freely flow into the Atlantic Ocean, most notably the Cross River in Nigeria's southeast and the Osun, Oyan, and Ogun Rivers in the countries southwest. The River Komadugu Gana and its feeders, as well as a few other rivers in northeastern Nigeria, flow into Lake Chad (Ismaila, 2017). The lake is naturally situated in the heart of a major drainage basin, at the point where the Republics of Nigeria, Chad, Niger, and Cameroon converge. Kainji Lake was created artificially in the late 1960s by the building of a dam (Kainji Dam) on Nigeria's longest and largest river, the Niger River. The nation's geographic topography varies from coastal swamps and the lower Niger basin valley to high plateaus in the north and mountains along the eastern fringe, as most parts of the country are bound by beneficial rivers and streams that are strewn throughout the country (ECN, 2007). Power supply is regarded as a developmental necessity in Nigeria, alongside highways, media transmission, and portable water. It is, without a doubt, the lifeblood of any nation's industrial development. Nigeria's hydropower potential is enormous, with hydropower accounting for roughly 19 percent of installed electric current capacity on a commercial basis. There are more than 18,600 MW of exploitable capacity in total. Surprisingly, only about 19 percent is currently tapped (Ismaila, 2006).

Nature has blessed Nigeria with abundant water supplies. Yearly precipitation decreases from a high of $3400 \mathrm{~mm}$ depth in the center of the Niger Delta region to $500 \mathrm{~mm}$ over the northern country's borders, with a roosted increase to $1400 \mathrm{~mm}$ over the central Jos Plateau (Oyewole et al., 2014). As a result, the eastern fringes of Adamawa and Cameroon receive a lot of rain, up to $2000 \mathrm{~mm}$ in comparison to the nation's low areas (Oyewole et al., 2014). Nigeria, as a nation, has considerable hydro potential, as evidenced by her massive rivers, numerous streams, and the various basins that are being formed. In Nigeria, rivers are naturally distributed throughout the country, 
providing potential sites for hydropower structures that can support both rural and urban communities (Fadare, 2008).

An assessment of the River Benue, River Kaduna, and the Cross River (at Makurdi, Shiroroa, and Ikom communities, respectively) revealed that a total capacity of around 4,650 MW is available, while the Mambilla River in Plateau is estimated to have a capacity of 2,330 MW (ECN, 2006). Hydropower is Nigeria's most widely used power source, dating back to 1968 when eight units with a total capacity of 760 MW were supposed to be operational. Despite the fact that there might not be a global consensus on what constitutes small hydropower, a 30 MW maximum limit has been carefully considered. As a result, the maximum rating in this current administration in the country is $30 \mathrm{MW}$ (Ismaila, 2017), and small hydro is divided into micro hydro (100 MW) and mini hydro (one KW), both of which come under the small hydropower (SHP) taxonomy. Hydropower capacity has recently been discovered in the river basins of 12 states, according to studies.

In addition, SHP capacity exists in almost all of Nigeria's regions. There are over 270 untapped areas with a total capacity of 734.3 MW (Oyedepo et al., 2018). According to ECN (2006), the federal government and privately owned companies in Nigeria have built about eight SHP stations with a total capacity of 39.0 MW. In the vicinity of the Jos Plateau, there are $2 \mathrm{MW}$ and $8 \mathrm{MW}$ stations at Kwall and Kurra falls in Kaduna, respectively, that were built by a private organization (NESCO) over 75 years ago. After the signing of a Memorandum of Understanding between the Energy Commission of Nigeria and the United Nations Industrial Organization's International Center on Small Hydro Power (ECN, 2007), one of the SHP's tasks has been to raise awareness at the local and state government levels. Some state governments are now expressing interest in developing possible hydropower sites for ECN.

\subsection{Solar Power Potential in Nigeria}

The sun is the most readily available and widely usable renewable energy source, capable of meeting the entire world's energy needs (IEA, 2012). Nigeria's position in the equatorial region, which receives a lot of sun radiation, is probably the best resource she has for encouraging sunlight-based energy generation. In Nigeria, the sun is evenly distributed, with an average solar radiation of $19.8 \mathrm{MJ} / \mathrm{m}^{2}$.day and a daily sunshine period of 6 hours, ranging from 3.5 hours near the coast to 9.0 hours near the far northern border (Vincent, 2012). Nigeria has enormous solar energy capacity due to its natural location within the earth's high Sun Belt. In Nigeria, solar panels or modules could generate around $185010^{3} \mathrm{GWh}$ of solar energy per year if they were used to cover $1 \%$ of the land area (Figure 4). This is more than 100 times the nation's current grid electricity use (Uzoma, 2011). In general, solar energy potential in Nigeria varies from $3.5 \mathrm{~kW} / \mathrm{m}$.day to $7.0 \mathrm{~kW} / \mathrm{m}$.day, based on an average daily sunshine of 4-7 hours (ECN, 2005; Oyedepo et al., 2018).

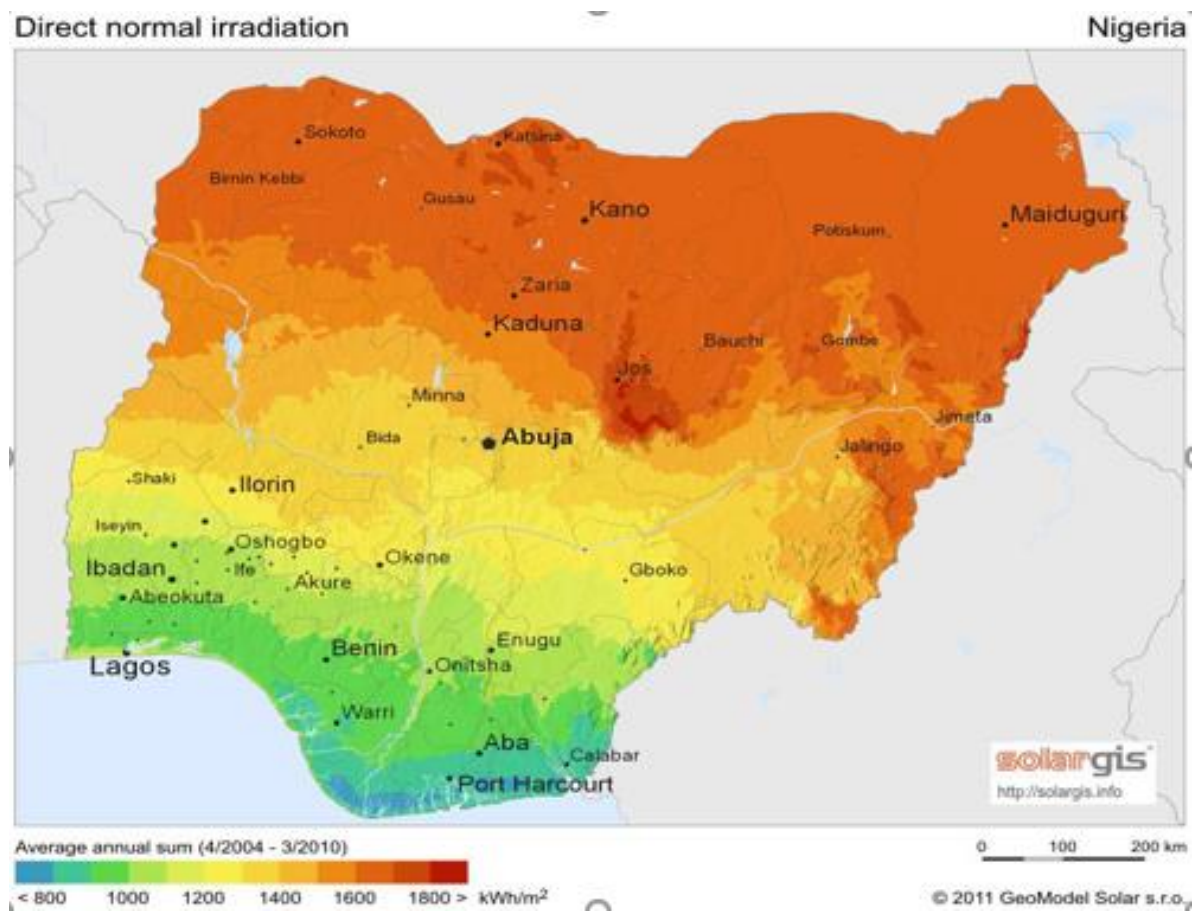

Figure 4. Crop zones of Nigeria (EIA, 2013) 
Solar energy can be used in two ways to generate electricity: solar electric conversion and solar-thermal conversion. The heating of water to generate steam to power turbines for large-scale centralized output is a solarthermal application. Solar-thermal devices, also known as concentrated solar power (CSP), use the sun's energy to generate electricity in a different way than solar cells (Oji et al., 2012). Many solar-thermal systems use a solar collector with a reflecting surface to concentrate sun rays onto a receiver that heats a liquid, usually water. This process of power production was not covered by the Federal Ministry of Power and Steel's Renewable Electricity Action Program (REAP), which was made public by the International Center for Energy, Environment, and Development in Nigeria (ICENDN).

The direct conversion of sunlight into electric current using photocells, which can be done in a centralized or decentralized manner, is known as solar-electric conversion. Photovoltaic technology, also known as solar-electric technology, converts sunlight directly into electrical energy (Oji et al., 2012). A photovoltaic system has a sense of balance to it, which includes component mounting structures, power equipment coordination, tracing structures, concentrator systems, and regenerating storage devices (Bernard et al., 2020). Solar electric conversion can, of course, be done on a small scale for standalone systems or on a large scale that is connected to the national grid (USCCTP, 2005). A solar cell's panel board is a set of modules that are mechanically and electrically connected. A module is a set of electrically coupled cells packed into a frame (solar panel) that can then be assembled into larger solar arrays. Photovoltaic (PV) cells are made up of different components known as semiconductors, such as silicon, which is the most commonly used (Oji et al., 2012). As light enters the cell, a small portion of it is stored within the semiconductor material, and the assimilated light's energy is transmitted through the semiconductor. Electrons become loose as a result of the force, allowing them to move freely (REAP, 2006).

In Nigeria, rural areas are home to more than $70 \%$ of the population. Since a society's level of energy availability is a function of its rate of growth and development, it is possible to alleviate Nigerians' suffering by making solar energy a viable choice. According to ECN and UNDP in 2005, the Sokoto Energy Research Center (SERC) and the National Center for Energy Research and Development (NCERD) under the supervision of the Energy Commission of Nigeria (ECN) have undertaken a number of pilot ventures, studies, and surveys, resulting in the installation of a number of PV-water pumping, electrification, and solar-thermal installations - solar crop drying (Oyedepo et al, 2018). Low and medium-power applications of solar energy include village electrification, water pumping, vaccine refrigeration, power supply to rural clinics and schools, and illumination of road signs and traffic lighting.

\subsection{Wind Energy Potential in Nigeria}

For the time being, wind power is not used in Nigeria to generate electricity. Nonetheless, the need to find a longterm solution to Nigeria's energy problems has prompted the government and independent researchers to consider the country's wind energy potential (Agbetuyi et al., 2012). Asiegbu and Iwuoha (2007) analyzed the wind in Umidike, Nigeria's southeast, and assessed its economic viability at a hub height of 65 meters above the ground with a yearly average wind speed of $5.36 \mathrm{~m} / \mathrm{s}$, using wind speed data from 1994 to 2003 . Ajayi (2010) used the Weibull statistical method to evaluate wind energy capacity in Ibadan, Nigeria, using ten-year daily wind speed data from 1995 to 2005 . The average wind speed in the city is $2.947 \mathrm{~m} / \mathrm{s}$, according to the results (Figure 5).

Ogbonnaya et al. (2009) investigated the prospects for wind energy in Nigeria using wind data from seven strategic cities for a period of 4 years: Abuja (Federal Capital Territory), Warri, Enugu, Jos, Ikeja, Calabar, and Sokoto. The yearly wind speed varied between 2.3 and $3.4 \mathrm{~m} / \mathrm{s}$ for places along the coast, and between 3.0 and $3.9 \mathrm{~m} / \mathrm{s}$ for highland regions and semi-arid areas at $10 \mathrm{~m}$ above the ground. According to the study's wind power potentials, Sokoto is capable of producing up to $97 \mathrm{MWh} / \mathrm{yr}$ of electricity. Both of these ingenuities realized, within the bounds of their uncertainties, that wind energy has a lot of potential for power generation. Aside from the coast and offshore areas, wind speeds are generally poor in the southern portion. Offshore territories stretching from Lagos to Ondo, Delta, Rivers, Bayelsa, and Akwa Ibom were investigated for the potential of harvesting strong wind energy throughout the year (Ajayi, 2010). Going inland, it was confirmed that the wind was strongest in Northern Nigeria's mountainous and hilly regions, while the hilly terrains of the middle belt and northern fringes revealed high potential for great wind energy generation. However, it was discovered that, due to the country's diverse geography, major contrasts would occur even within the same neighborhood. Wind speeds vary from 1.4 to $3.0 \mathrm{~m} / \mathrm{s}$ in the southern parts of the country to 4.0 to $5.12 \mathrm{~m} / \mathrm{s}$ in the far north (Agbetuyi et al., 2012). In general, peak wind speed was found to occur between April and August for most of the sites studied. 


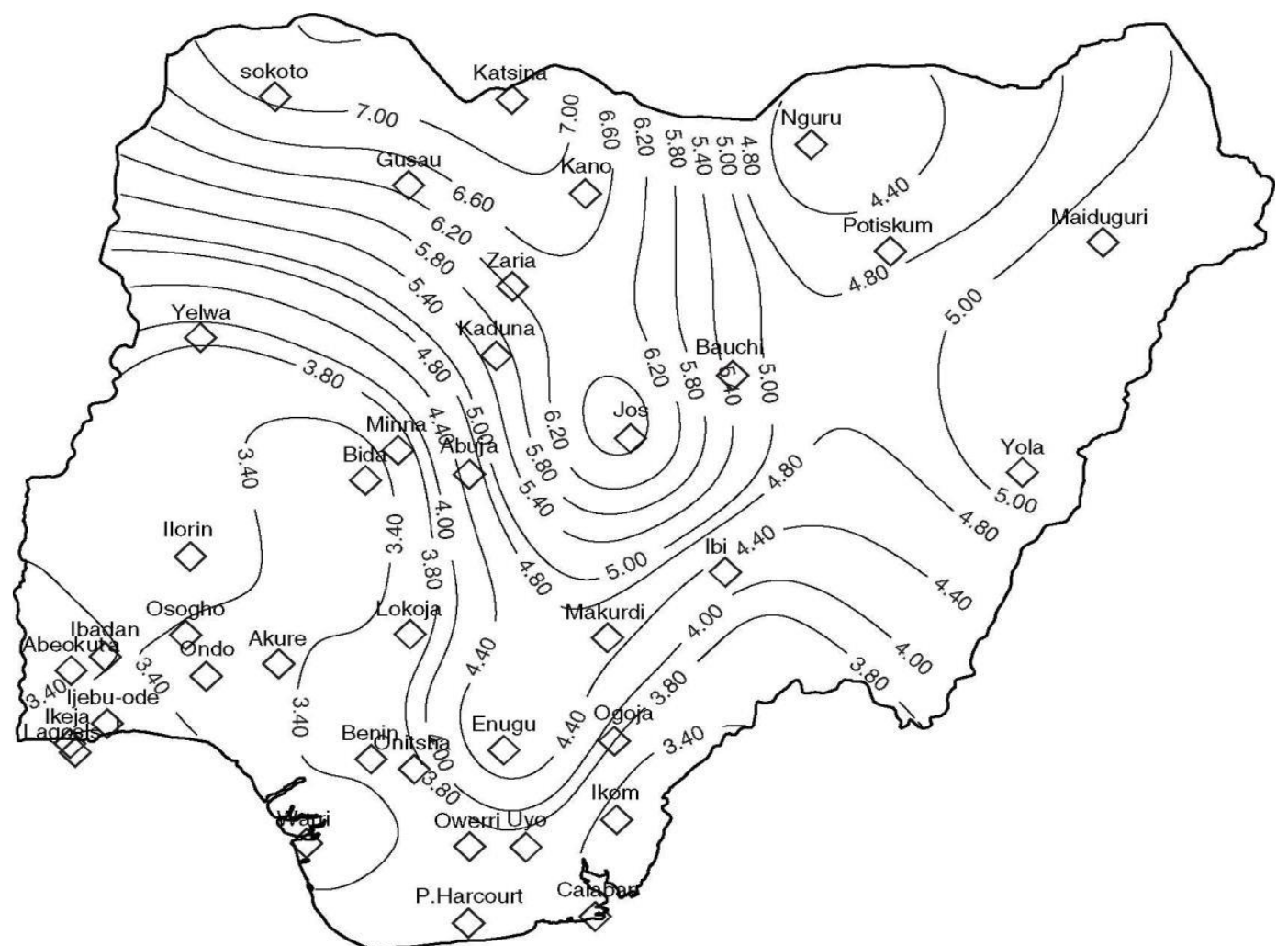

Figure 5. Isovents in m/s determined from 40 year's measurements at $10 \mathrm{~m}$ height

(NIMET, 2014)

Further investigation of these wind energy resources revealed that the country's northern, southern, and southeastern regions have tremendous potential for harnessing wind energy, with promising wind speeds of up to $8.70 \mathrm{~m} / \mathrm{s}$ in northern Nigeria (Agbetuyi et al., 2012). As a result, the northern part of the country will be the best place to start harvesting wind energy in Nigeria. Currently, wind energy's share of total energy consumption in the public sector is negligible. In Sayyan Gidan Gada, Sokoto State, no wind power plant is connected to the national electricity grid; only a few individual wind power plants were built in five northern states in the early 1960s, primarily to power water pumps and village electrification (Nnaji et al., 2010). Initially, a study found that the definite exploitable reserve of wind energy at a height of 10 meters could range from $8 \mathrm{MWh} / \mathrm{yr}$ in Yola, Adamawa State, to $51 \mathrm{MWh} / \mathrm{yr}$ in the highland areas of Plateau State's Jos Plateau. So, in Nigeria, the wind energy capacity is $97 \mathrm{MWh} / \mathrm{yr}$ in Sokoto, and these values increase at 30 meters (Agbetuyi et al., 2012).

\subsection{Geothermal Energy Potential in Nigeria}

The heat energy that comes from the Earth's core is known as geothermal energy. It comes from two sources: heat produced by radioactive disintegration of different isotope elements and heat generated during the Earth's formation (Eyinla et al., 2016). The temperature beneath the moderately thin earth's crust can reach $1300^{\circ} \mathrm{C}$, and it's been estimated that one out of every hundred of the tappable heat from the continents' beneath, to a depth of 6 $\mathrm{km}$, is equal to the energy available by mankind for the next 10,000 years (Eyinla et al., 2016). More than 9,000 megawatts of power were supplied in 2004 from approximately 250 geothermal power plants in 22 countries around the world (Sambo, 2018), and these plants provide a reliable supply of electricity to more than 60 million people, mostly in developing countries. African countries with geothermal energy potential are those crisscrossed by the East African Rift Valley. Tanzania, Uganda, Djibouti, Ethiopia, Kenya, and Eritrea are among these countries. In Nigeria, two geothermal sites have been identified: the Ikogosi Warm Springs in Ondo State and the Wikki Warm Springs in Bauchi State (ECN, 2006).

A geothermal energy framework consists of three main components: a heat source, a reservoir, and a working liquid or gas, with the latter serving as a heat transporter from the source to the power plant (Grasby et al., 2011). To convert geothermal fluids to electric current, three types of power plant technology are used: dry steam power plants, which use geothermal steam directly to drive mechanical turbines; flash steam power plants, which pull highly pressurized hot water into a lower-pressure expander and use the resultant flashed energized steam to drive turbines; and binary-cycle power plants, which move discretely hot water into a lower-pressure expander and use 
the resultant flashed energized steam to drive turbine. As a result, the secondary liquid flashes to energetic vapor, which powers the turbines. Farming, industrial and domestic hot water use, and individual and residential district heating are examples of direct thermal uses of geothermal energy. Heat pumps are also widely used in temperate climates (Abraham et al., 2014).

Geothermal power plants typically range in size from $20 \mathrm{MW}$ to $60 \mathrm{MW}$, with individual geothermal wells typically ranging in size from $4 \mathrm{MW}$ to $10 \mathrm{MW}$ (Ghomshei, 2010). To avoid interference, distinct spacing of at least $200 \mathrm{~m}$ to $300 \mathrm{~m}$ is necessary between thermal wells. In comparison to coal, supply from geothermal power plants has an average availability of about $90 \%$, while coal has an availability of $75 \%$. According to Abraham et al., (2014), the Olkaria Geothermal Plant in Kenya has been operating for more than 20 years with an availability factor of approximately $98 \%$.

In Nigeria, the potential for geothermal energy locked in the earth's crust is virtually limitless (Figure 6). Apart from the two known geothermal resource zones in Nigeria, high geothermal gradient patterns have been discovered in the Lagos sub-basin, Lagos State; the Okitipupa ridge, Okitipupa, Ondo State; and the Auchi-Agbede line near the Benin flank, Edo State, as well as the Abakaliki anticlinorium in Ebonyi State (ECN, 2006). In the database on geothermal energy in Nigeria, there is no credible details (Abraham et al., 2014). This is without prejudice to promising studies in Nigerian universities' geology and petroleum geology departments.

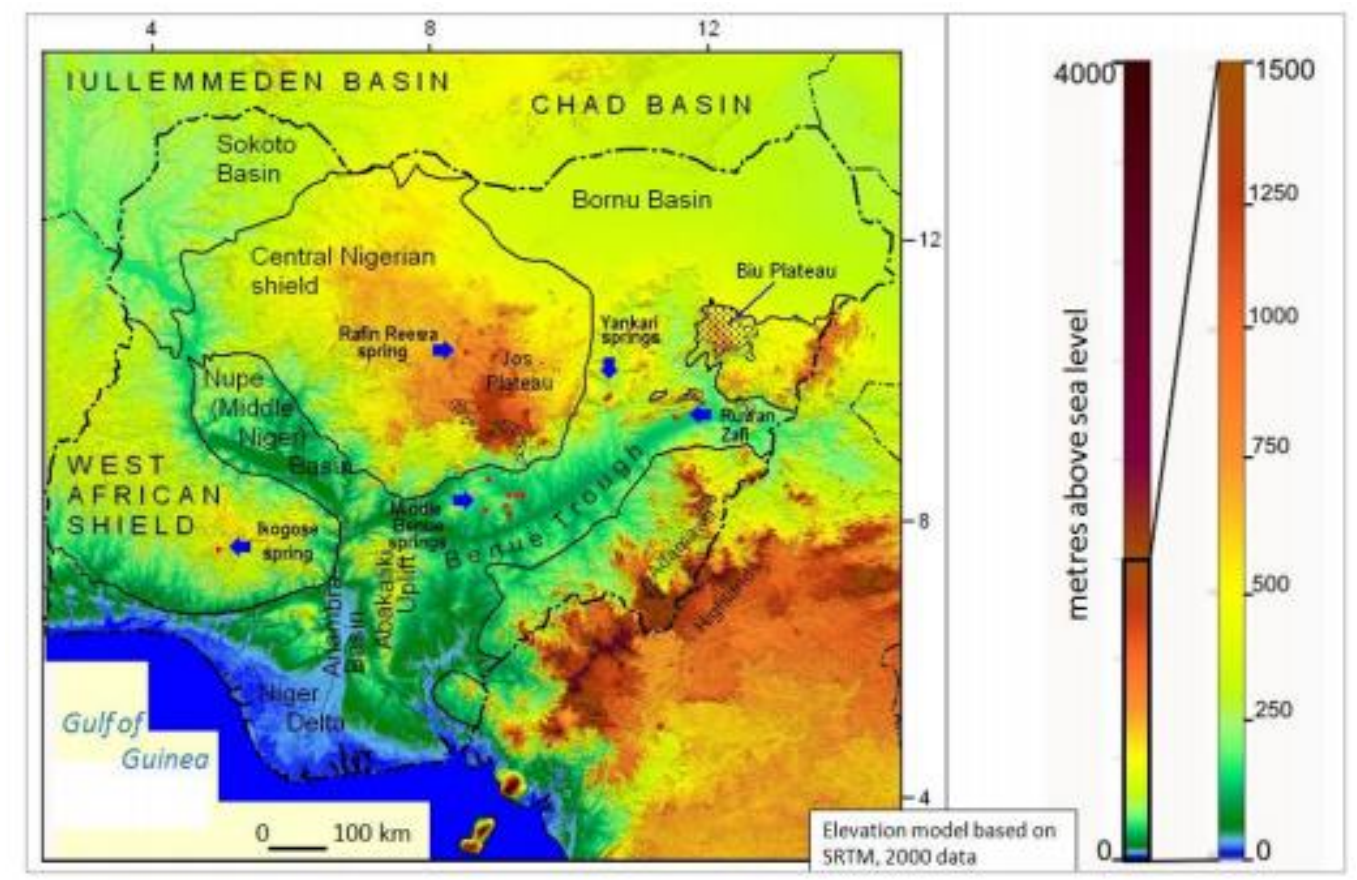

Figure 6. Geothermal gradient of Nigeria (Kwaya and Kurowska, 2018)

\subsection{Marine Energy Potential in Nigeria}

Waves powered by wind, gravitational tidal ranges, thermal gradients between warm surface water and colder water at depths greater than $1000 \mathrm{~m}$, salinity gradients, and marine currents have immense marine-energy potentials, but what is economically exploitable is negligible (Collins et al., 2015). It has been possible to extract useful resources from the world's oceans for more than a few centuries. Nonetheless, genuine interest in R\&D by a few, mostly European nations did not emerge until the oil crisis of the mid-1970s (Carbon Trust, 2005). Because of these countries' commitment to harnessing ocean resources, a large number of technological advancements are closer to commercial viability than at any other time in history (WEC, 2004a).

Given Nigeria's geographical position (Figure 7), power from the sea should be a key component of the long-term vision for a safe, cost-effective, and clean energy supply in the near future (Collins et al., 2015). Over 66\% of the earth's atmosphere is covered by seas and oceans. As a result, they are the world's largest solar collectors. The sun's heat and the mechanical energy of tides and waves can also be delivered by the sea. Although the moon's gravitational force is responsible for moving the tides, the wind is responsible for energizing the sea waves. The Atlantic Ocean coastline of Nigeria stretches for $800 \mathrm{~km}$, from Badagry in Lagos State to Bakassi in Cross River State. Tides in coastal regions vary in height from 100 to $300 \mathrm{~cm}$, with an average incursion length of 30 to $40 \mathrm{~km}$ 
(Amoo, 2018). Ocean tides have a maximum height of $5 \mathrm{~m}$ all over the world. Wave and tidal energy sources are concentrated off Asia's and Europe's western coasts, respectively.

According to the World Energy Council, the world's wave energy potential is estimated to be 2,000 GW, with a yearly potential of around $2 \times 106 \mathrm{GWh}$ for the power market (IEA, 2006a). The power wave regime along the West African coast is $10 \mathrm{~kW} / \mathrm{m}$.

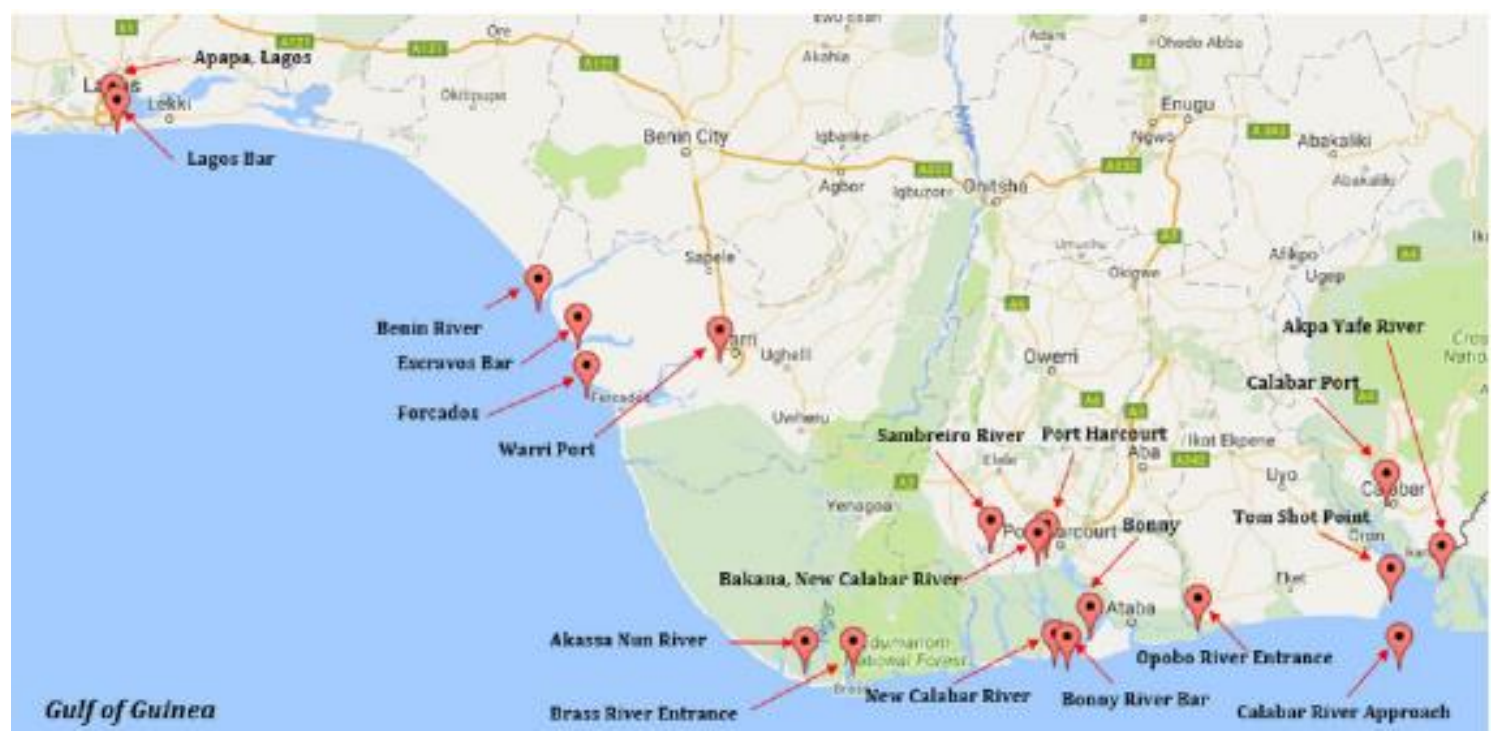

Figure 7. The 19 tidal stations on Nigerian coastline (Amoo, 2018)

The shore of South Africa has energy potentials of 40 to $50 \mathrm{~kW} / \mathrm{m}$, while the shoreline of the United Kingdom has a portion of the world's best potentials of about $70 \mathrm{~kW} / \mathrm{m}$ (IEA, 2006d). Nigeria has a good number of educational institutions that can conduct groundbreaking research and development on marine resources (Collins et al., 2015). Calabar has the maximum tidal height of $3.07 \mathrm{~m}$, Bonny has $2.40 \mathrm{~m}$, Akassa has $1.80 \mathrm{~m}$, and Lagos has $1.3 \mathrm{~m}$, according to Collins et al., (2015). As a result, the federal government's energy masterplan could include the construction of a tidal power plant for electricity generation. Departments of Oceanography at universities, as well as the Nigerian Institute for Oceanographic and Marine Research (NIOMR) in Lagos State, are among the educational institutions. Nonetheless, there are currently no known existing parastatals in Nigeria engaged in R\&D innovative work (ECN, 2005).

\section{Conclusion}

Considering the energy need, energy status, energy mix and renewable energy potentials of Nigeria while reviewing the literature, the following conclusions were arrived at: the current energy supply in Nigeria is far below her need, there is room for tremendous energy generation from different sources for the nation that is naturally endowed with great deal of renewable energy potentials.

\section{References}

Abraham, Ema Michael, Alile, Owens \& Murana, Kehinde Ayofe. (2014). Structural mapping of Ikogosi Warm Spring area using Aeromagnetic Derivatives and Euler depth estimates. International Journal of Natural and Applied Science, 3(2), 15-20. https://doi.org/10.1186/s40517-014-0018-9

Agbetuyi A. Felix, Akinbulire T. O., Abdulkareem A., \& Awosope C. O. A. (2012). Wind Energy Potential in Nigeria. International Electrical Engineering Journal (IEEJ), 3(1), 595-601.

Ajayi, O. O. (2010). "The Potential for Wind Energy in Nigeria, 2010", Wind Engineering, 34(3), 303-312. https://doi.org/10.1260/0309-524X.34.3.303

Akorede M. F., Ibrahim O., Amuda S. A., Otuoze A. O., \& Olufeagba B. J. (2017). Current Status and Outlook of Renewable Energy Development in Nigeria. Nigerian Journal of Technology (NIJOTECH), 36(1), January 2017, 196-212. http://dx.doi.org/10.4314/njt.v36i1.25

Akinyemi, O., Efobi, U., Asongu, S., \& Osabuohien, E. (2019). Renewable energy, trade performance and the conditional role of finance and institutional capacity in sub-Sahara African Countries. Energy Policy, 132, 490-498. https://doi.org/10.1016/j.enpol.2019.06.012 
Amoo L. M. (2018). Techno-economic assessment of energy production potential from tidal streams in Nigeria. International Journal of Energy and Environmental Engineering, 9, 81-98. https://doi.org/10.1007/s40095017-0256-2

Asiegbu, A. D., \& Iwuoha (2007). "G.S. Studies of wind resources in Umudike, South East Nigeria - An assessment of economic viability," Journal of Engineering and Applied sciences, 2(10), 1539-1541.

Audu, O. K., \& Aluyor, E. O. (2012). "The Potential of Bioenergy and Biofuels Tech. Development I Nigeria." Petroleum Technology Development Journal (ISSN 1595-9104), 1(4), 207-210.

Bernard Knutel, Anna Pierzynska, Marcin Debowski, Przemysław Bukowski \& Arkadiusz Dyjakon (2020). Assessment of Energy Storage from Photovoltaic Installations in Poland Using Batteries or Hydrogen. Energies, 2020, 13, 4023. https://doi.org/10.3390/en13154023

Carbon Trust (2005). Detailed reports on technology, cost and resource for wave and tidal ECI report on variability of UK marine energy resources.

CIA (2012). The World factbook: Nigeria. http://www.cia.gov/library/publications/the world factbook/index.html. Accessed on 24-08-2020.

Collins N. Nwaokocha, Mufutau A. Waheed \& Abayomi T. Layeni. (2015). Estimation of Tidal Power Potential of Nigeria Coastal Area. Renewable Energy and Sustainable Development, Nova Science Publishers, Inc.

ECN (2005). Phyllis, database for biomass and waste, Energy research Centre of the Netherlands.

Energy Commission of Nigeria (ECN) (2006). Draft National Energy Masterplan. (Accessed in January 2015) www.energy.gov.ng. Accessed on 5-10-2014.

ECN and UNDP (2005). "Nigeria Renewable Energy Master Plan (REMP)" www.areanet.org/fileadmin/user_uploada/AREA/AREA_downloads/AREA_Conferene_09/Presentations/N igeria_Renewable_Energy_Masterplan.pdf. Accessed October, 2020.

Ekundayo P. Mesagan, O. Yasiru Alimi, \& K. Adekunle Adebiyi. (2018). "Population Growth, Energy Use, Crude Oil Price, and the Nigerian Economy". Икономически изследвания, 2, 115-132.

Elehinafe, F. B., Okedere, O. B., Fakinle, B. S, \& Sonibare, J. A. (2017). Assessment of sawdust of different wood species in Southwestern Nigeria as source of energy, Energy Sources, Part A: Recovery, Utilization, and Environmental Effects, 39(18), 1901-1905. https://doi.org/10.1080/15567036.2017.1384869

Energy Information Administration (EIA) (2013). "Nigeria - Analysis, Updated last December, 2013”; Accessed in March, 2014 www.eia.gov/countries/cab.cfm?fips=ni

Energy Commission of Nigeria (ECN) (2007). Renewable Energy Master Plan (Draft). www.energy.gov.ng. Accessed in August, 2014.

Energy Commission of Nigeria (ECN) (2009). National Energy Policy.www.energy.gov.ng. Accessed in April, 2015.

Eyinla Dorcas S., Oladunjoye Michael A., Ogunribido Thompson H. T., \& Odundun Olumuyiwa A. (2016). An Overview of Geothermal Energy Resources in Nigeria. Environtropica, Vols. 12 \& 13, 61-71.

Ghomshei, M. M. (2008). New Frontiers in Geothermal Energy. Presentation given at 7thWorld Wind Energy Conference, June 23-26, 2008, Kingston, Ontario.

Ghomshei, M. M. (2010). Canadian Geothermal Power Prospects. World Geothermal Congress 2010. Bali, Indonesia, 25-29 April, 2010.

Grasby, S. E., Allen, D. M., Chen, Z., Ferguson, G., Jessop, A., Kelman, M., Ko, M., Majorowicz, J., Moore, M., Raymond, J., \& Therrien, R. (2011). Geothermal energy resource potential of Canada. Natural Resources Canada, Geological Survey of Canada, Ottawa, Ont. Geological Survey of Canada, Open File 6914. https://doi.org/10.4095/288745

IEA (2006d). Renewable energy RD \& D priorities report. International Energy Agency, OECD, Paris. www.iea.org. Accessed in May, 2013.

IEA (2012). Energy balance for Nigeria, OECD/IEA. http://www. data.iea.org. Accessed on 07-09-20113.

Energy Information Administration (EIA) (2013). "Nigeria - Analysis, Updated last December, 2013"; Accessed in March, 2014 www.eia.gov/countries/cab.cfm?fips=ni 
Ighodaro, C. A. U. (2010). Co-Integration and Causality Relationship between Energy Consumption and Economic Growth: Further Empirical Evidence for Nigeria. Journal of Business Economics and Management, 11(1), 97-111. https://doi.org/10.3846/jbem.2010.05

Ismaila, H. Z. (2006). "Hydro Power Resources in Nigeria, ECN, 2006," http://www.unido.org/fileadmin/import/52413_Mr._Ismaila_Haliru_Zarma.pdf, Accessed in August, 2012.

Ismaila Haliru Zarma (2017). HYDRO POWER RESOURCES IN NIGERIA. Conference: 2nd Hydro Power for Today Conference International Centre on Small Hydro Power (IC-SHP), Hangzhou, China 2006.

Kwaya M. Y., \& Kurowska, E. (2018). Geothermal Exploration in Nigeria - Country Update. Proceedings, 7th African Rift Geothermal Conference.

Liu Zhenya (2015). Global Energy Development: The Reality and Challenges. Global Energy Interconnection. https://doi.org/10.1016/B978-0-12-804405-6.00001-4

LSMEMR (2013). Ten Point Agenda, Lagos State Economic Empowerment Development Strategy. Vision 20:20:20 and Millennium Development Goals (MDGs).

National Bureau of Statistics (2019). Petroleum Products Imports and Consumption (Truck Out) Statistics. $\begin{array}{lll}\text { Acessed } & 10^{\text {th }} & \text { October, }\end{array}$ https://www.nigerianstat.gov.ng/pdfuploads/Petroleum_Products_Importation_and_Consumption.

National Population Commission (NPC) (2006). National Census Figures. Accessed January, 2015. www.npc.gov.gn.

NIMET (2014). Isovents in $\mathrm{m} / \mathrm{s}$ determined from 40 year's measurements at $10 \mathrm{~m}$ height, obtained from Nigeria meteorological department, Oshodi, Lagos State, Nigeria.

Nnaji, C. E., Uzoma, C. C., \& Chukwu, J. O (2010). "The role of renewable energy resources in poverty alleviation and sustainable Development in Nigeria," Continental J. Social Sciences, 3, 31-37, 2010. http://www.wiloludjournal.com> Retrieved October 2013

Nwachukwu M. U., Ezedinma N. F., \& Jiburum U. (2014). Comparative Analysis of Electricity Consumption among Residential, Commercial and Industrial Sectors of the Nigeria's Economy. Journal of Energy Technologies and Policy, 4(3), 2014.

Oji J. O., Idusuyi N., Aliu T. O., Petinrin M. O., Odejobi O. A., \& Adetunji A. R. (2012). Utilization of Solar Energy for Power Generation in Nigeria. International Journal of Energy Engineering 2012, 2(2), 54-59. https://doi.org/10.5923/j.ijee.20120202.07

Okafor, E. C. N., \& Joe-Uzuegbu, C. K. A (2010). Challenges to Development of Renewable Energy for Electric Power Sector In Nigeria. International Journal of Academic Research, 2(2), 211-216.

Okafor, F. N. (2017). Improving Electric Power Sector Performance: The Role of Nigeria Electricity Regulatory Commission. Nigerian Academy of Engineering 2017 Public Lecture held on March 29, 2017 at University of Lagos, Akoka, Lagos, Nigeria, 1-14.

Olaide M. Aderoju, Guerner A. Dias and Zhour Echakraoui (2017). Assessment of Renewable Energy Sources \& Municipal Solid Waste for Sustainable Power Generation in Nigeria. IOP Conf. Series: Earth and Environmental Science 95 (2017) 042043. https://doi.org/10.1088/1755-1315/95/4/042043

Oyedepo, S. O., Babalola, O. P., Nwanya, S. C., Kilanko, O., Leramo, R. O., Aworinde, A. K., Adekeye, T., Oyebanji. J. A., Abidakun, A. O., \& Agberegha, O. L. (2018). Towards a Sustainable Electricity Supply in Nigeria: The Role of Decentralized Renewable Energy System. European Journal of Sustainable Development Research, 2(4), 40. https://doi.org/10.20897/ejosdr/3908

Oyewole, J. A., Thompson, A. M., Akinpelu, J. A., \& Jegede O. O (2014). Variation of Rainfall and Humidity in Nigeria. Journal of Environment and Earth Science, 4(2), 29-37.

REAP (2006). Provision of framework to implement the Renewable Electricity Policy andRegulatory Guidelines.

Sambo, A. S. (2008). Strategic Developments in Renewable Energy in Nigeria. International Association for Energy Economics, Third Quarter 2008, 15-19.

Sambo, A. S. (2018). Energy Crisis in Nigeria: Engineers' Proactive Steps towards Energy Self-Sufficiency. Lecture as the First in the Series of the Distinguished Lectures in honour of Engr. Dr. E. J. S. Uujamhan, at the University of Benin, Benin City, on the 6th Day of April, 2018, 1-27. 
Simonyan K. J., \& Fasina O. (2013). Biomass Resources and Bioenergy Potentials in Nigeria. African Journal of Agricultural Research, 8(40), 4975-4989. 17 October, 2013. DOI: 10.5897/AJAR2013.6726

Sonibare, J. A. (2010) Air Pollution Implications of Nigeria's Present Strategy on Improved Electricity Generation. Energy Policy, 38, 5783-5789. https://doi.org/10.1016/j.enpol.2010.05.029

Sumit Sharma, Rajendra Meena, Amit Sharma \& Pawan kumar Goyal (2014). Biomass Conversion Technologies for Renewable Energy and Fuels: A Review Note. IOSR Journal of Mechanical and Civil Engineering (IOSR$J M C E$ ), Volume 11, Issue 2 Ver. I, 01-00. https://doi.org/10.9790/1684-11232835

Ugwu H. U. (2012). Structure of Energy Consumption in Manufacturing Industries. M.Eng Dissertation, Department of Mechanical Engineering, University of Nigeria, Nsukka, 23.

UNDP (2005). Energy and the challenge of sustainability. World Energy Assessment, United Nations Development Programme, UNDESA and World Energy Council, ISBN 9211261260, New York, http://www. undp.org/energy/activities/wea/drafts-frame.html Accessed in April, 2013.

Uzoma, C. C. (2011). "Renewable Energy Penetration in Nigeria: A Study of The South-East Zone," Continental J. Environmental Sciences 5 Renewable Electricity Action Program (REAP) 2006 Federal Ministry of Power and Steel Nigeria.

WEC (2004a). Comparison of energy systems using life cycle assessment - special report. World Energy Council, July, London.

World Bank (2006). 'At Loggerheads? Agricultural expansion, poverty reduction, and environment in the tropical forests', Washington, DC: World Bank.

\section{Copyrights}

Copyright for this article is retained by the author(s), with first publication rights granted to the journal.

This is an open-access article distributed under the terms and conditions of the Creative Commons Attribution license (http://creativecommons.org/licenses/by/4.0/). 